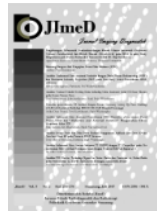

Jurnal Imejing Diagnostik (JImeD) 7 (2021) 114-120

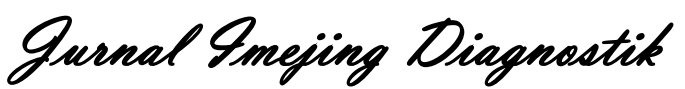

e-ISSN 2621-7457, p-ISSN 2356-301X

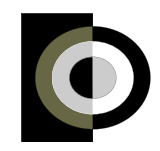

http://ejournal.poltekkessmg.ac.id/ojs/index.php/jimed/index

\title{
Analisis Kompetensi Petugas Proteksi Radiasi di Fasilitas Radiologi Diagnostik dan Intervensional dari Perspektif Inspektur Keselamatan Nuklir - BAPETEN.
}

\author{
Puji. Hastuti ${ }^{1}$, Sjahrul .Meizar Nasri ${ }^{2}$, Adi Drajat Noerwarsana ${ }^{3}$ \\ ${ }^{1,2)}$ Fakultas Kesehatan Masyarakat, Program Studi Kesehatan dan Keselamatan Kerja Universitas Indonesia, \\ Depok, Indonesia \\ 3) Badan Pengawas Tenaga Nuklir, Jakarta, Indonesia \\ Corresponding Author: Puji Hastuti \\ e-mail: p.hastuti@bapeten.go.id
}

Received: July $29^{\text {th }}, 2021$; Revised: July $30^{\text {th }}$, 2021; Accepted: July $31^{\text {st }}, 2021$

\begin{abstract}
Background: Radiation Protection Officer (PPR) plays an important role in ensuring radiation safety supervision in diagnostic and interventional radiology facilities. To support this, high level competencies are absolutely necessary. The purpose of this competency analysis study is to obtain an overview of the competence of radiation protection officers working in diagnostic and interventional radiology facilities. Methods: This study is a descriptive as well as quantitative research. The study was conducted by collecting primary data through filling out questionnaires with an assessment by 6 inspectors with respondents assessed as 40 PPR from 40 diagnostic radiology facilities spread across West Java, East Java, Batam, Riau Islands. Validity and Reliability testing was carried out in this study. PPR competency level analysis was carried out by testing statistical descriptions and testing the frequency distribution using Statistical Product and Service Solution (SPSS) for Windows 21.

Results: The results of PPR competence in 40 diagnostic and interventional radiology facilities by 6 Nuclear Safety Inspectors showed that the level of PPR competence in diagnostic radiology facilities was at a high level. This is related to the selection of nuclear safety inspectors who are in the (good) and (very good) range Conclusion: Based on the computational analysis using the SPSS version 21 program, it shows that the level of hard competency (technical competency) and soft competency of PPR in diagnostic and interventional radiology facilities is at a level above 3 or the average is at a level close to high. Further research needs to be done with a more comprehensive competency statement item variable and with a larger number of inspectors and PPR with a research time span long enough in order to describe the actual PPR competencies on the field.
\end{abstract}

Keywords: Radiation Protection Officer; Diagnostic and Interventional Radiology Facilities; Competency Analysis.

\section{Pendahuluan}

Peningkatan jumlah fasilitas radiasi yang semakin pesat dan pemberlakuan Masyarakat Ekonomi Asean (MEA) telah menjadi tantangan tersendiri dalam pengawasan pemanfaatan radiasi. Salah satu modalitas yang memanfaatkan radiasi di bidang medik adalah fasilitas radiologi diagnostik dan intervensional. Pada tahun 2019 menurut data dari Balis Bapeten 2.0 tercatat hampir 1890 jumlah pesawat sinar - $\mathrm{X}$ yang tersebar di Indonesia. Fasilitas radiologi diagnostik dan intervensional selain memiliki manfaat juga memiliki potensi bahaya radiasi yang besar baik bagi pekerja, pasien, masyarakat dan lingkungan. Pada tahun 2020 faktor manusia masih menjadi penyebab kedua terjadinya kesalahan/ kecelakaan radiasi di fasilitas radiologi diagnostik dan intervensional sebesar $23.3 \%$ (Omar, 2020). Untuk memperkecil kesalahan faktor manusia, IAEA telah mengeluarkan rekomendasi kepada badan pengawas untuk menunjuk personil yang kompeten dalam melakukan pengawasan radiasi di instansi/perusahaan pemegang izin yaitu Petugas Proteksi Radiasi (PPR) (GSR Part 3 IAEA. 2014).

Petugas proteksi radiasi (PPR) adalah personil yang kompeten secara teknis dalam bidang proteksi radiasi sesuai dengan jenis pemanfaatannya, yang ditunjuk oleh pemegang izin untuk mengawasi pelaksanaan persyaratan peraturan perundanganundangan (GSR Part 3 IAEA. 2014). PPR memegang peranan penting dalam memastikan pengawasan keselamatan radiasi di instansi/perusahaannya (Aris 
S, 2009), tugas dan tanggung jawab PPR diatur dalam Peraturan Kepala BAPETEN No.16 Tahun 2014 antara lain :

a. Mengidentifikasi persyaratan Proteksi dan Keselamatan Radiasi sesuai dengan jenis pemanfaatan Sumber Radiasi Pengion.

b. Mengusulkan upaya-upaya pemenuhan persyaratan dan ketentuan dalam peraturan perundang-undangan ketenaganukliran kepada Pemegang Izin.

c. Membantu Pemegang Izin dalam menyusun dan menetapkan Program Proteksi dan Keselamatan Radiasi.

d. Memberikan konsultasi, instruksi teknis dan administratif secara lisan atau tertulis kepada personil lain tentang pelaksanaan Program Proteksi dan Keselamatan Radiasi.

e. Mengawasi pelaksanaan Program Proteksi dan Keselamatan Radiasi.

f. Mengkaji ulang efektivitas penerapan Program Proteksi dan Keselamatan Radiasi.

g. Melaporkan pengawasan penerapan Program Proteksi dan Keselamatan Radiasi kepada Pemegang Izin.

h. Membantu Pemegang Izin dalam memutakhirkan Program Proteksi dan Keselamatan Radiasi.

i. Mengidentifikasi kebutuhan dan mengorganisasi kegiatan pelatihan.

j. Memastikan ketersediaan dan kelayakan perlengkapan Proteksi Radiasi dan memantau pemakaiannya.

k. Melaporkan kepada Pemegang Izin jika Pekerja Radiasi menerima dosis melebihi Pembatas Dosis.

1. Melakukan kendali akses di Daerah Pengendalian.

m. Melaksanakan latihan penanggulangan dan pencarian fakta dalam hal kedaruratan.

Untuk menunjang tugas dan tanggung jawab tersebut maka kompetensi kerja yang tinggi meliputi hard competency dan soft competency mutlak diperlukan (Goffin and Woycheshin, 2006) dikarenakan kompetensi memiliki pengaruh positif terhadap pelaksanaan tugas dan tanggung jawab individu (Martini et al. 2018).

Kompetensi adalah seperangkat pengetahuan, keterampilan, kemampuan, ciri-ciri kepribadian dan pengetahuan yang bertujuan menghasilkan manajemen yang efektif (Langbert, 2000). Dua jenis kompetensi yang saat ini berkembang dengan pesat adalah hard competency (kompetensi teknis) dan soft competency. Definisi hard competency dan soft competency dibedakan dimana hard technical skill mengacu pada keterampilan dalam kategori teknis, berurusan dengan data dan keterampilan yang terkait dengan pengetahuan teknis khusus dan keterampilan berorientasi tugas (Ashbaugh, 2003) sedangkan soft behavioral skill yang dibutuhkan di tempat kerja.

Kompetensi teknis atau fungsional (technical/functional competence) atau dapat juga disebut dengan hard skill/hard competency adalah kompetensi yang berfokus pada pelaksanaan atau penyelesaian tugas berdasarkan deskripsi kerja teknis, Kompetensi teknis menggambarkan penerapan pengetahuan dan keterampilan yang dibutuhkan untuk melakukan secara efektif dalam pekerjaan tertentu atau kelompok pekerjaan dalam organisasi. Jenis kompetensi ini sangat selaras dengan pengetahuan dan keterampilan atau "knowhow" yang dibutuhkan untuk kinerja yang sukses. Sedangkan soft competency berkaitan dengan kemampuan mengelola proses kerja, keterampilan interpersonal, manusia, orang atau perilaku yang diperlukan untuk menerapkan keterampilan teknis dan pengetahuan di tempat kerja" (Weber et al. 2009; De Villiers, 2010). Soft Competency dipandang sebagai pelengkap Hard Competency dan merupakan persyaratan untuk kinerja di tempat kerja yang sukses.

Salah satu metode untuk melakukan pengukuran tingkat kompetensi adalah Analisis kompetensi . Pengertian analisis kompetensi secara sederhana adalah segala bentuk pendekatan analisis sistematis yang menjelaskan beban kerja atau tugas seseorang, baik aktivitas maupun perilakunya, konteks pekerjaan di lingkungan kerja dan segala tuntutan dan persyaratan pekerjaan, yang terdiri dari pengetahuan, keterampilan, dan ability (kemampuan) secara detail dan menyeluruh (Moeheriono 2009).

Ketiadaan analisis kompetensi bagi PPR yang bekerja di fasilitas radiologi diagnostik dan intervensional juga menyebabkan sulit terukurnya unjuk kerja kritis petugas proteksi radiasi, terjadinya stagnasi dalam pengembangan skema sertifikasi dikarenakan tidak adanya informasi terkait kompetensi aktual PPR setelah bekerja di fasilitas dan peningkatan mutu kompetensi yang berjalan lambat sehingga peran PPR kurang efektif meminimalisir terjadinya kesalahan dan kecelakaan radiasi di fasilitas radiologi diagnostik dan intervensional.

Analisis kompetensi PPR pada penelitian ini dilakukan dari persepsi inspektur keselamatan nuklir dikarenakan inspektur memiliki kewenangan untuk memastikan dan melakukan penilaian bahwa keselamatan radiasi telah dilakukan sesuai dengan 
peraturan UU yang berlaku. Kajian ini bertujuan mengetahui tingkat kompetensi petugas proteksi radiasi yang mencangkup hard competency dan soft competency PPR yang bekerja di fasilitas radiologi diagnostik dan intervensional dalam melakukan pengawasan keselamatan radiasi di tempat kerja.

\section{Metodologi}

Penelitian ini merupakan penelitian kuantitatif dengan pendekatan deskriptif. Instrumen penelitian dilakukan dengan cara pengumpulan data primer melalui pengisian kuesioner dengan penilaian oleh 6 inspektur dengan responden yang dinilai adalah 40 PPR dari 40 fasilitas radiologi diagnostik yang tersebar di Jawa Barat (Karawang- Cirebon), Jawa Timur, Batam, Kepulauan Riau.

Waktu pengambilan kuesioner dilakukan dari rentang Tahun November 2019 - Maret 2020. Kuesioner dirancang singkat dengan jumlah pertanyaan untuk mengetahui identitas responden sebanyak 4 pertanyaan sedangkan untuk menganalisis kompetensi sebanyak 5 item pertanyaan yang didesain sebagai pernyataan tertutup dan pilihan jawaban telah tersedia.

Setiap jawaban responden diberi skor nilai 1 (satu) - 4 (empat) dengan menggunakan skala likert 4 = Sangat Baik dengan pernyataan (SB), 3 = Baik dengan pernyataan (SB), 2 = Cukup Baik dengan pernyataan $(\mathrm{SB}), 1=$ Kurang Baik dengan pernyataan $(\mathrm{KB})$.

Analisa data diolah menggunakan Statistical Product and Service Solution (SPSS) for windows versi 21 berdasarkan jumlah kuesioner yang terkumpul, kemudian dilakukan analisa sebagai berikut :

1. Pengujian uji validitas dilakukan pada penelitian ini untuk mengetahui apakah alat ukur yang digunakan mengukur apa yang perlu diukur menggunakan korelasi Pearson Product Moment.

2. Pengujian reliabilitas masing-masing instrumen yang digunakan, peneliti menggunakan koefisien cronbach alpha $(\alpha)$.

3. Pengujian analisa tingkat kompetensi PPR dilakukan dengan pengujian deskripsi statistik dan uji distribusi frekuensi.

\section{Hasil dan Pembahasan}

\section{Deskripsi Data Responden}

Hasil sebaran data responden data berdasarkan jenis kelamin, usia, pendidikan serta masa kerja diperoleh rincian data sebagai berikut :

\section{Jenis Kelamin}

Data pada tabel 1 menunjukkan bahwa mayoritas responden berjenis kelamin laki laki yaitu sejumlah
25 orang $(62,5 \%)$ dan 15 orang berjenis kelamin perempuan $(37,5 \%)$.

Tabel 1. Data Responden Berdasarkan Jenis Kelamin

\begin{tabular}{lllc}
\hline No. & Jenis Kelamin & Jumlah & Persentase \\
\hline 1. & Laki Laki & 25 Orang & $62,5 \%$ \\
2. & Perempuan & 15 Orang & $37,5 \%$ \\
\hline & Jumlah & 40 Orang & $100 \%$ \\
\hline
\end{tabular}

2. Usia

Data pada tabel 2 menunjukkan bahwa mayoritas responden berusia 20 - 30 Tahun yaitu sejumlah 11 orang $(27,5 \%), 20$ orang berusia $31-40$ tahun $(50 \%)$ dan 9 Orang berusia $41-50$ tahun $(22,5$ $\%)$.

Tabel 2. Data Responden Berdasarkan Usia

\begin{tabular}{cclc}
\hline No. & Jenis Kelamin & Jumlah & Persentase \\
\hline 1. & $20-30$ Tahun & 11 Orang & $27,5 \%$ \\
2. & $31-40$ Tahun & 20 Orang & $50 \%$ \\
3. & $41-50$ Tahun & 9 Orang & $22,5 \%$ \\
\hline & Jumlah & 40 Orang & $100 \%$ \\
\hline
\end{tabular}

3. Tingkat Pendidikan

Tingkat pendidikan didistribusikan berdasarkan 2 tingkat pendidikan yaitu DIV/S1 dan DIII. Data pada tabel 3 menunjukkan bahwa mayoritas responden berpendidikan DIV/S1 yaitu sejumlah 32 (80\%), dan 8 berpendidikan DIII (20\%).

Tabel 3. Data Responden Berdasarkan Tingkat

\begin{tabular}{cccc}
\multicolumn{4}{c}{ Pendidikan } \\
\hline No. & Jenis Kelamin & Jumlah & Persentase \\
\hline 1. & DIV/S1 & 32 Orang & $80 \%$ \\
2. & DIII & 8 Orang & $20 \%$ \\
\hline & Jumlah & 40 Orang & $100 \%$ \\
\hline
\end{tabular}

Ditinjau dari tingkat pendidikan PPR dirasakan sudah cukup kompeten untuk melakukan pekerjaan sebagai PPR di fasilitas radiologi diagnostik dan intervensional yang memiliki tugas dan tanggung jawab tertentu.

\section{Masa Kerja}

Ditinjau dari masa kerja PPR berdasarkan pada tabel 4 menunjukkan bahwa mayoritas responden memiliki masa kerja selama 0 - 5 Tahun sebanyak 10 Orang $(27,5 \%)$, masa kerja selama 6 - 10 tahun sebanyak 26 orang ( $65 \%$ ) dan dengan masa kerja selama $11-15$ tahun sebesar 4 Orang (10\%). Jika dilihat dari lamanya bekerja maka PPR yang memiliki seharusnya memiliki pengalaman kerja yang lebih memadai yang dibutuhkan dalam proses penyelesaian masalah yang dihadapi dalam tugas dan tanggung jawab terkait PPR. 
Tabel 4. Data Responden Berdasarkan Lama Kerja

\begin{tabular}{cllc}
\hline No. & Jenis Kelamin & Jumlah & Persentase \\
\hline 1. & $0-5$ Tahun & 10 Orang & $27,5 \%$ \\
2. & $6-10$ Tahun & 26 Orang & $65 \%$ \\
3. & $11-15$ Tahun & 4 Orang & $10 \%$ \\
\hline & Jumlah & 40 Orang & $100 \%$ \\
\hline
\end{tabular}

\section{Hasil Pengujian Instrumen Kajian}

Pengujian statistik terhadap instrumen kajian dilakukan dengan dua cara yaitu uji validitas yang menunjukkan tingkat kesahihan hasil uji dan koefisien reliabilitas dari hasil uji terhadap kuesioner menunjukkan tingkat keandalan.

\section{Uji Validitas dan Reliabilitas Variabel Kompetensi}

Uji Validitas kompetensi untuk penelitian ini diperoleh hasil sebagai berikut :

Tabel 5. Hasil Pengukuran validitas Variabel

\begin{tabular}{|c|c|c|c|c|c|c|c|}
\hline & & Q.1 & Q.2 & Q.3 & Q.4 & Q.5 & Total Item \\
\hline & Pearson Correlation & 1 & $0,592^{* *}$ & $0,399^{*}$ & $0,439^{* *}$ & 0,259 & $0,587^{* *}$ \\
\hline \multirow[t]{3}{*}{ P.1 } & Sig. (2-tailed) & & 0,000 & 0,011 & 0,005 & 0,107 & 0,000 \\
\hline & $\mathrm{N}$ & 40 & 40 & 40 & 40 & 40 & 40 \\
\hline & Pearson Correlation & $0,592^{* *}$ & 1 & $0,679^{* *}$ & $0,679^{* *}$ & $0,609^{* *}$ & $0,876^{* *}$ \\
\hline \multirow[t]{3}{*}{ P. 2} & Sig. (2-tailed) & 0,000 & & 0,000 & 0,000 & 0,000 & 0,000 \\
\hline & $\mathrm{N}$ & 40 & 40 & 40 & 40 & 40 & 40 \\
\hline & Pearson Correlation & $0,399^{*}$ & $0,679^{* *}$ & 1 & $0,612^{* *}$ & $0,682^{* *}$ & $0,867^{* *}$ \\
\hline \multirow[t]{3}{*}{ P.3 } & Sig. (2-tailed) & 0,011 &, 000 & & 0,000 & 0,000 & 0,000 \\
\hline & $\mathrm{N}$ & 40 & 40 & 40 & 40 & 40 & 40 \\
\hline & Pearson Correlation & $0,439^{* * *}$ & $0,679^{* *}$ & $0,612^{* *}$ & 1 & $0,599^{* *}$ & $0,835^{* *}$ \\
\hline \multirow[t]{3}{*}{ P.4 } & Sig. (2-tailed) & 0,005 & 0,000 & 0,000 & & 0,000 & 0,000 \\
\hline & $\mathrm{N}$ & 40 & 40 & 40 & 40 & 40 & 40 \\
\hline & Pearson Correlation & 0,259 & $0,609^{* *}$ & $0,682^{* *}$ & $0,599^{* *}$ & 1 & $0,824^{* *}$ \\
\hline \multirow[t]{3}{*}{ P.5 } & Sig. (2-tailed) & 0,107 & 0,000 & 0,000 & 0,000 & & 0,000 \\
\hline & $\mathrm{N}$ & 40 & 40 & 40 & 40 & 40 & 40 \\
\hline & Pearson Correlation & $0,587^{* *}$ & $0,876^{* *}$ & $0,867^{* *}$ & $0,835^{* *}$ & $0,824^{* *}$ & 1 \\
\hline \multirow[t]{2}{*}{ Total Item } & Sig. (2-tailed) & 0,000 & 0,000 & 0,000 & 0,000 & 0,000 & \\
\hline & $\mathrm{N}$ & 40 & 40 & 40 & 40 & 40 & 40 \\
\hline
\end{tabular}

**. Correlation is significant at the 0.01 level (2-tailed).

*. Correlation is significant at the 0.05 level (2-tailed).

Untuk menyimpulkan validitas dapat dilihat dari angka pada Total Item, yang merupakan korelasi antara skor item dengan skor total item. Interpretasinya yaitu dengan cara mengkonsultasikan dengan $r$-table. Butir pertanyaan dikatakan valid jika nilai r-hitung yang merupakan nilai dari Total Item lebih besar dari r-tabel (Total Item $\left.>\mathrm{r}_{\text {-table}}\right)$. Dengan menggunakan jumlah responden sebanyak 40 , dengan $\mathrm{dk}=\mathrm{n}-2=40-2=38$ dan taraf signifikansi ( $\alpha$ ) 0,05 maka diperoleh $r$-tabel $=0,312$. Berdasarkan tabel di atas diperoleh nilai Total Item > r-tabel dengan demikian dapat disimpulkan bahwa 5 item pertanyaan berkategori valid.

Hasil perhitungan reliabilitas variabel menggunakan SPSS for windows versi 21.00 dapat diperoleh hasil sebagai berikut:
Tabel 6. Hasil Pengukuran Reliabilitas Variabel

\begin{tabular}{cc}
\hline Cronbach's Alpha & N of Items \\
\hline 0,859 & 5 \\
\hline
\end{tabular}

Dari output SPSS di atas menunjukan tabel Reliability Statistic pada SPSS yang terlihat koefisien reliabilitas pada nilai Cronbach's Alpha adalah 0,859 . Sedangkan metode pengambilan keputusan pada uji reliabilitas biasanya menggunakan batasan 0,6. Reliabilitas kurang dari 0,6 adalah kurang baik, sedangkan 0,7 dapat diterima dan diatas 0,8 adalah baik. Berdasarkan hasil diatas terlihat bahwa kuesioner/instrumen penelitian telah memenuhi ketentuan reliabilitas data yaitu sebesar 0,859 . Karena nilainya lebih besar $(0,859>0,6)$, maka dapat disimpulkan bahwa konstruksi pernyatan pada item soal tersebut berkategori reliabel. 


\section{Analisis Kompetensi PPR}

Analisis Kompetensi PPR dilakukan melalui analisis komputasi data dengan dilakukan pengujian distribusi frekuensi dan persentase variabel kompetensi dan pengujian deskripsi statistic.

\section{Uji Distribusi Frekuensi /Persentase dan Uji Deskripsi Statistik Variabel}

Pengukuran terhadap variabel kompetensi dilakukan melalui 5 variabel pernyataan dimana memuat pernyataan hard competency (kompetensi teknis) dan soft competency PPR yang akan dilakukan penilaian oleh Inspektur Keselamatan Nuklir. Lima pernyataan tersebut adalah:

Tabel 7. Variabel Pernyataan Kuesioner

\begin{tabular}{|c|c|c|c|}
\hline No & Pernyataan & Kompetensi & \multirow{6}{*}{$\begin{array}{l}\text { Skala Pengukuran } \\
4=\text { Sangat Baik } \\
\text { dengan pernyataan } \\
(\mathrm{SB}), \\
3=\text { Baik dengan } \\
\text { pernyataan (SB), } \\
2=\text { Cukup Baik } \\
\text { dengan pernyataan } \\
(\mathrm{SB}), \\
1=\text { Kurang Baik } \\
\text { dengan pernyataan } \\
(\mathrm{KB})\end{array}$} \\
\hline$\overline{P 1}$ & $\begin{array}{l}\text { Bagaimana pemahaman petugas terhadap } \\
\text { ketentuan dan sanksi dalam pemanfaatan sumber } \\
\text { radiasi pengion yang telah ditetapkan dalam } \\
\text { peraturan perundang-undangan? }\end{array}$ & $\begin{array}{l}\text { Hard Competency (Kompetensi } \\
\text { Teknis) }\end{array}$ & \\
\hline $\mathrm{P} 2$ & $\begin{array}{l}\text { Bagaimana pemahaman petugas terhadap teknik } \\
\text { proteksi radiasi di tempat kerja? }\end{array}$ & $\begin{array}{l}\text { Hard Competency (Kompetensi } \\
\text { Teknis) }\end{array}$ & \\
\hline P3 & $\begin{array}{l}\text { Bagaimana kemampuan komunikasi dan } \\
\text { koordinasi petugas dengan unit kerja lain yang } \\
\text { terkait proteksi dan keselamatan radiasi? }\end{array}$ & Soft Competency & \\
\hline P4 & $\begin{array}{l}\text { Bagaimana perilaku petugas di tempat kerja? } \\
\text { (Kehadiran, kedisiplinan, dll) }\end{array}$ & Soft Competency & \\
\hline P5 & $\begin{array}{l}\text { Bagaimana kemampuan kerjasama petugas dalam } \\
\text { membantu pemegang izin untuk memenuhi } \\
\text { persyaratan proteksi dan keselamatan radiasi? } \\
\text { (membuat SOP, pemeriksaan kesehatan, } \\
\text { pemantauan dosis, penggunaan alat proteksi } \\
\text { radiasi, dll) }\end{array}$ & Soft Competency & \\
\hline
\end{tabular}

Perhitungan distribusi frekuensi dilakukan dengan menghitung skor terhadap masing masing pernyataan yang telah valid dan reliabel pada masing masing kuesioner kajian. Kuesioner dalam penelitian ini menggunakan pendekatan skala likert 1 (satu ) 4 (empat). Dalam menentukan skala terlebih dahulu dicari nilai intervalnya dengan menggunakan rumus sebagai berikut :

\section{Interval}

$$
=\frac{\text { Bobot nilai tertinggi }- \text { Bobot nilai terendah }}{\text { Banyaknya kelas }}
$$

$$
=\frac{4-1}{4}=0,75
$$

Setelah mengetahui nilai intervalnya maka dapat dketahui nilai rerataan responden. Skala tersebut adalah sebagai berikut :

Tabel 8. Skala Interval Kompetensi

\begin{tabular}{cc}
\hline Interval Nilai & Tingkat Kompetensi \\
\hline $3.25-4$ & Sangat Baik \\
$3.25-2.50$ & Baik \\
$2.50-1.75$ & Cukup Baik \\
$1,75-1$ & Kurang Baik \\
\hline
\end{tabular}

Berdasarkan output yang diperoleh dengan SPSS versi 21 for windows maka distribusi frekuensi untuk variabel kompetensi dengan kategori kurang baik, cukup baik, baik dan sangat baik untuk 5 pernyataan kuesioner, ditinjau dari tabel 9 maka distribusi frekuensi berdasarkan hasil perhitungan interval diatas adalah output P.1 dari 40 data institusi kesehatan terdapat 1 yang menyatakan cukup baik $(2,5 \%)$, terdapat 34 yang menyatakan baik $(85 \%)$, terdapat 5 yang menyatakan sangat baik $(12,5 \%)$, dan tidak ada yang menyatakan kurang baik.

Output P.2 dari 40 data institusi kesehatan terdapat 10 yang menyatakan cukup baik $(25 \%)$, terdapat 21 yang menyatakan baik $(52,5 \%)$, terdapat 9 yang menyatakan sangat baik $(22,5 \%)$, dan tidak ada yang menyatakan kurang baik. Output P.3 dari 40 data institusi kesehatan terdapat 2 yang menyatakan kurang baik (5\%), terdapat 6 yang menyatakan cukup baik (15\%), terdapat 20 yang menyatakan baik (50\%), dan terdapat 12 yang menyatakan sangat baik (30\%).

Ditinjau dari output P4 dari 40 data institusi kesehatan terdapat 1 yang menyatakan kurang baik $(2,5 \%)$, terdapat 5 yang menyatakan cukup baik $(12,5 \%)$, terdapat 23 yang menyatakan baik $(57,5 \%)$, dan terdapat 11 yang menyatakan sangat baik $(27,5 \%)$. Berdasarkan output P.5 dari 40 data institusi kesehatan terdapat 2 yang menyatakan kurang baik $(5 \%)$, terdapat 6 yang menyatakan cukup baik $(15 \%)$, terdapat 22 yang menyatakan baik $(55 \%)$, dan terdapat 10 yang menyatakan sangat baik $(25 \%)$. 
Tabel 9. Hasil Pengukuran Distribusi Frekuensi Variabel

\begin{tabular}{|c|c|c|c|c|c|c|c|c|c|c|}
\hline \multirow[t]{3}{*}{ Kategori } & \multicolumn{10}{|c|}{ Pernyataan } \\
\hline & \multicolumn{2}{|c|}{$\mathrm{P} 1$} & \multicolumn{2}{|c|}{$\mathrm{P} 2$} & \multicolumn{2}{|c|}{ P3 } & \multicolumn{2}{|c|}{ P4 } & \multicolumn{2}{|c|}{ P5 } \\
\hline & Frek & $(\%)$ & Frek & $(\%)$ & Frek & $(\%)$ & Frek & $(\%)$ & Frek & $(\%)$ \\
\hline Kurang Baik & 0 & 0 & 0 & 0 & 2 & 5,0 & 1 & 2,5 & 2 & 5,0 \\
\hline Cukup Baik & 1 & 2,5 & 10 & 25,0 & 6 & 15,0 & 5 & 12,5 & 6 & 15,0 \\
\hline Baik & 34 & 85,0 & 21 & 52,5 & 20 & 50,0 & 23 & 57,5 & 22 & 55,0 \\
\hline Sangat Baik & 5 & 12,5 & 9 & 22,5 & 12 & 30,0 & 11 & 27,5 & 10 & 25,0 \\
\hline
\end{tabular}

Jika dilihat secara keseluruhan penilaian kompetensi PPR di 40 instansi oleh 6 Inspektur Keselamatan Nuklir maka diperoleh rata rata hasil penilaian untuk 5 pernyataan kompetensi adalah baik (3). Dari distribusi frekuensi dapat diperoleh gambaran bahwa level kompetensi PPR di fasilitas radiologi diagnostik berada pada level tinggi ini terkait dengan pilihan penilaian inspektur keselamatan nuklir yang berada pada kisaran 4 (baik) dan 3 (sangat baik). Untuk mengetahui secara lebih rinci distribusi frekuensi variabel kompetensi digunakan uji deskripsi statistik untuk menentukan mean tiap item pernyataan. Adapun hasil ringkasnya dapat dilihat dalam tabel dibawah ini :

Tabel 10. Hasil Pengukuran Deskripsi statistik Item Pernyataan

\begin{tabular}{cccc}
\hline Item Pernyataan & $\mathrm{N}$ & Sum & Mean \\
\hline P.1 & 40 & 124,00 & 3,1000 \\
P.2 & 40 & 119,00 & 2,9750 \\
P.3 & 40 & 122,00 & 3,0500 \\
P.4 & 40 & 124,00 & 3,1000 \\
P.5 & 40 & 120,00 & 3,0000 \\
\hline
\end{tabular}

Berdasarkan tabel tersebut mean skor tertinggi ada pada dimensi pernyataan 1 dan 4 sebesar $3.1 \%$ yaitu Pemahaman petugas terhadap ketentuan dan sanksi pemanfaatan sumber radiasi pengion yang telah ditetapkan dalam peraturan perundangundangan.dan perilaku petugas di tempat kerja (Kehadiran, Kedisiplinan). Sedangkan skor terendah ada pada dimensi pernyataan 2 pemahaman petugas terhadap proteksi radiasi di tempat kerja sebesar 2.9 $\%$ menunjukkan bahwa kompetensi teknis terkait pemahaman proteksi radiasi masih harus ditingkatkan. Upaya peningkatan kompetensi pemahaman petugas terhadap proteksi radiasi dapat dilakukan dengan pelatihan internal proteksi radiasi di tempat kerja, pembentukan forum Group Discussion (FGD) antara badan pengawas, manajemen fasilitas dan PPR, pengembangan skema sertifikasi pelatihan PPR atau skema pelatihan penyegaran (refresher training) PPR yang diselenggarakan oleh BAPETEN.

Upaya peningkatan kompetensi yang dapat dilakukan bagi petugas proteksi radiasi di masa yang akan datang adalah:

1. Menyusun strategi nasional berdasarkan kebutuhan dengan memperhatikan sumber daya dan kemampuan yang tersedia untuk pelatihan untuk pengembangan kompetensi pendidikan dan pelatihan yang berkelanjutan.

2. Merancang program pelatihan nasional di bidang keselamatan radiasi yang akan memenuhi semua kebutuhan yang teridentifikasi
3. Pengembangan dan peningkatan pelatihan penyegaran harus mencakup pembelajaran dari insiden masa lalu atau kecelakaan di fasilitas serupa dan kecelakaan yang pernah terjadi

4. Menetapkan sistem kualifikasi dan sertifikasi nasional serta sistem manajemen mutu kompetensi pekerja radiasi tingkat nasional (standar kompetensi kerja petugas proteksi radiasi - SKKNI).

\section{Kesimpulan}

Berdasarkan komputasi analisis dengan program SPSS versi 21 menunjukkan bahwa tingkat hard competency (kompetensi teknis) dan soft competency PPR di fasilitas radiologi diagnostik dan intervensional berada pada level diatas 3 atau rata rata berada pada level mendekati tinggi. Perlu dilakukan penelitian lebih lanjut dengan variabel item pernyataan kompetensi yang lebih komprehensif dan dengan jumlah inspektur dan PPR yang lebih banyak dengan rentang waktu penelitian cukup lama agar dapat tergambarkan kompetensi aktual PPR di lapangan.

\section{Daftar Pustaka}

Alsabbah, Mohammed, \& Ibrahim, Hazril (2013) Recruitment and Selection Process and Employee Competence (Soft and Hard) Outcome: an Important Area for Future 
Research, Human Resource management Research, 3 (3):82-90.

Aris S. (2009). Peningkatan Hasil Uji Kompetensi Personil Sebagai Strategi Pengawasan Tenaga Nuklir. Jurnal Widya Nuklida.. Vol (9).

Goffin, R. D., \& Woycheshin, D. E. (2006). An Empirical Method Of Determining Employee Competencies/ Ksaos From Task-Based Job Analysis. Military Psychology, 18(2), 121-130.

International Atomic Energy Agency. (2000). Building Competence In Radiation Protection And The Safe Use Of Radiation Sources. Safety Standards Series No. RsG-1-4. Iaea. Vienna.

International Atomic Energy Agency (Iaea) (2014), General Safety Requirement Part 3, No.Gsr Part 3, Radiation Protection And Safety Of Radiation Sources: International Basic Safety Standards.

Martini, I. A. O., Rahyuda, I. K., Sintasih, D. K., \& Priartini, P. S. (2018). The Influence Of Competency On Employee Performance Through Organizational Commitment Dimension. Iosr Journal Of Business And Management (Iosr-Jbm), 20(2), 29-37.

Miller, Rankin And Neathey. (2001). Competency Frameworks In Uk Organization, Cipd, London

Moeheriono. (2009). Pengukuran Kinerja Berbasis Kompetensi: Competency Based Human
Resource Management. Jakarta: Ghalia Indonesia.

Mohammed A. Alsabbah, Hazril Izwar Ibrahim (2013). Employee Competence (Soft And Hard) Outcome Of Recruitment And Selection Process. American Journal Of Economics. 3(C): 67-73. Doi:10.5923/C.Economics.201301.12.

Omer Kasalak, Derya Yakar (2020). Patient Safety In Radiology Frequency And Distribution Of Incident Types. Acta Radiologica Journal. Https://Doi.Org/10.1177/02841851209373 86.

Peraturan Kepala Bapeten Nomor 16 Tahun 2014 Tentang Surat Izin Bekerja Petugas Tertentu Yang Bekerja Di Instalasi Yang Memanfaatkan Sumber Radiasi Pengion.I

Purwanto, Didik. (2008). Dibanding Ipk Soft Skill Lebih Dibutuhkan Industri. Kedaulatan Rakyat, Edisi 12 September 2008.

Spencer, L. M. \& Spencer, S.M. (1993). Competence At Work: Models For Superior Performance. New York: John Wiley \& Sons, Inc.

Weber, M. R., Finley, D. A., Crawford, A. \& Rivera, D. (2009). An Exploratory Study Identifying Soft Skill Competencies In Entry-Level Managers. [Article]. Tourism \& Hospitality Research, 9(4), 353-361.

Wibowo. (2017). Manajemen Kinerja. Edisi Kelima. Gramedia. Jakarta. 